\title{
Crown architecture and leaf habit are associated with intrinsically different light-harvesting efficiencies in Quercus seedlings from contrasting environments
}

\author{
Jordán ESTESO-MARTínEZ ${ }^{\mathrm{a}}$, Fernando VALLADARES ${ }^{\mathrm{b}}$, Jesús Julio CAMARERO ${ }^{\mathrm{a}}$, \\ Eustaquio GIL-PELEGRÍ́N ${ }^{\mathrm{a} *}$ \\ ${ }^{a}$ Unidad de Recursos Forestales, Centro de Investigación y Tecnología Agroalimentaria, Gobierno de Aragón, Apdo. 727, 50080 Zaragoza, Spain \\ ${ }^{\mathrm{b}}$ Centro de Ciencias Medioambientales, CSIC, Serrano 115, 28006 Madrid, Spain
}

(Received 2 November 2005; accepted 13 December 2005)

\begin{abstract}
Crown architecture and light-harvesting efficiency $(E a)$ were compared in seedlings of eight Quercus species from contrasting environments. Several morphological variables were measured after one year of growth under the same environmental conditions. Ea was estimated with the 3-D model Y-plant. The species were classified in four groups according to their Ea: Q. rubra-Q. alba $>$ Q. faginea-Q. pyrenaica $>Q$. robur-Q. ilex-Q. coccifera $>Q$. suber. Principal component analysis revealed that the constraining morphological variables for maximizing $E a$ were the total number of leaves and the variability of internode length. Two contrasting growth models were associated with distinct environments and significantly different $E a$ : evergreen, Mediterranean species (e.g. $Q$. suber), which showed a multilayered crown of many small leaves rendering low Ea, versus deciduous, non-Mediterranean temperate species (e.g. Q. rubra), which showed the opposite characteristics.
\end{abstract}

light-harvesting efficiengy / Mediterranean / Quercus / self-shading / Y-plant

Résumé - Architecture de la couronne et feuillage sont associés intrinsèquement avec différentes efficiences de capture de la lumière chez les semis de chêne en conditions environnementales contrastées. L'architecture des couronnes et l'efficience de capture de la lumière $(E a)$ ont été comparées chez des semis de 8 espèces de chênes dans des environnements très différents. Plusieurs caractéristiques morphologiques ont été mesurées après un an de croissance sous les mêmes conditions environnementales. Ea a été estimé avec le modèle 3-D Y-plant. Les espèces ont été classées en 4 groupes selon leur Ea $: Q$. rubra-Q. alba $>Q$. faginea- $Q$. pyrenaica $>Q$. robur-Q. ilex-Q. coccifera $>Q$. suber. Une analyse en composantes principales a révélé que les caractéristiques morphologiques contraignantes pour maximiser $E$ a étaient le nombre total de feuilles et la variabilité de la longueur de l'internode. Deux modèles très différents ont été associés avec des environnements distincts et avec $E a$ significativement différent : arbres à feuilles persistantes, les espèces méditerranéennes (par exemple $Q$. suber) présentent une couronne multicouche avec beaucoup de petites feuilles rendant Ea faible, par opposition aux espèces tempérées (par exemple Q. rubra) non méditerranéennes caducifoliées qui montrent des caractéristiques opposées.

éfficience de capture de la lumière / méditerranéen / Quercus / auto ombrage / Y-plant

\section{INTRODUCTION}

Light availability is a critical and heterogeneous ecological factor to which plant species have adapted their physiology and structure $[2,10,13,22]$. Light harvesting by plant crowns is influenced by a range of architectural traits including leaf elevation angle and internode length [43,46,49]. Mutual shading between neighbour leaves is the result of plant architecture and the spatial position of the light source. Different species exhibit different architectural traits and different phylogenetic constraints to maximize light capture, but within a given species light harvesting can be significantly modified by means of plastic phenotypic adjustments that lead to contrasting degrees of self-shading in sun and shade phenotypes [46]. Causes and consequences of self-shading have received exten-

\footnotetext{
*Corresponding author: egilp@aragon.es
}

sive attention [17], and they are still the focus of many studies $[20,40,50]$. Light availability can be a limiting factor in low light environments such as forest understories $[7,8,12,15]$ or a stress factor in open areas with high radiation loads [3,23]. In high-light environments, photooxidation and photoinhibition can take place when the irradiance needed for plant assimilation is exceeded, which is especially frequent if other stress factors such as drought are present $[45,48]$. Under these high light conditions self-shading may be favorable for avoiding light and thermal stresses. Contrastingly, under low light conditions, self-shading may be disadvantageous since it reduces light harvesting, which negatively affects plant performance $[19,44,47,50]$.

The connections between structure and function of plant developmental patterns in relation to light harvesting have received renewed attention during the last years [33]. However, most studies have focused on modeling instead of performing 


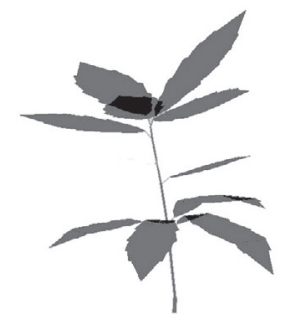

Q. rubra

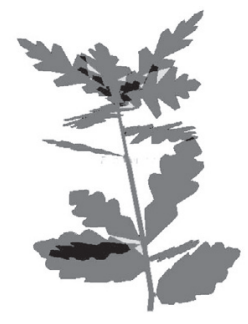

Q. pyrenaica

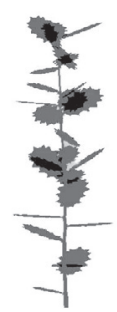

Q. coccifera
Figure 1. Examples of three contrasting crown morphologies of Quercus seedlings as reconstructed by the 3-D architectural model Y-plant. Dark foliage areas indicate mutual shade among leaves.

direct measurements of the light really harvested by the plant crown and by the individual leaves within the foliage [27,30, 35]. This lead Pearcy and Yang (1996) to develop the analytical software Y-plant to reconstruct three-dimensional models of plants based on real geometric measurements (Fig. 1) and to calculate light harvesting efficiency by actual plants at a given latitude and date. Y-plant has since then been successfully used in a number of functional and ecophysiological studies of plants $[11,33,34,45]$.

The aim of this study is to compare the light-harvesting efficiencies of seedlings of eight oak (Quercus) species differing in their morphological features, developmental pattern and provenance environments. Simulation analyses based on Y-plant and direct morphological measurements are used to explore form-functional suites of traits that could be associated with different developmental patterns in this phylogenetically homogeneous but ecologically heterogeneous group of species. It is expected that contrasting morphologies are associated with contrasting light harvesting efficiencies in species from different provenance environments due to the different selective pressures operating on the trade-off between maximizing light harvesting and avoiding high-light stress caused by high irradiance. The developmental pattern of leaf emergence is another aspect to be added to the suite of factors that influences light harvesting. Some species as $Q$. suber expand their leaves simultaneously (flushing leafing) while others unfold their leaves sequentially over extended periods of time (successive leafing; see Tab. I). The eight oak species studied differed markedly on their pattern of leaf emergence. Whether these developmental patterns are associated with other architectural features and how they specifically influence light harvesting is still poorly understood [20]. Oaks show a broad distribution in the Northern Hemisphere living in a wide range of biomes from temperate deciduous forests to Mediterranean machia and tropical forests [14]. In addition to their great worldwide ecological and economical importance, oaks constitute an appropriate group of species to test if environmental characteristics are associated with intrinsically different crown architectures and developmental patterns.

\section{MATERIALS AND METHODS}

\subsection{Plant material and experimental conditions}

Seedlings of several Quercus species were used as the subject of the measurements (Tab. I). We selected a wide range of oak species according to their provenance environment and main distribution area $[1,18,21]$. The species were: $Q$. alba L., $Q$. coccifera L., $Q$. faginea Lam., $Q$. ilex L. subsp. ballota (Desf.) Samp. (hereafter $Q$. ilex), $Q$. pyrenaica Willd., $Q$. robur L., $Q$. rubra L. and $Q$. suber L. All species belong to the Quercus taxonomic section within subgenus Quercus, excepting Q. rubra which is included in the Lobatae section [29]. Seeds obtained in Zaragoza province (NE Spain) were used for some evergreen Mediterranean $(Q$. coccifera, $Q$. ilex) and deciduous transitional sub-Mediterranean (Q. faginea, Q. pyrenaica) oaks. Seeds for the rest of species were obtained from two guarantied providers for European ("El Serranillo" Forest Breeding Station, Ministry of Environment, Spain) and American species, respectively (Sandeman Seeds, The Croft, Sutton, UK). Provenance zones of seeds were characteristic for each species [38]. Seed selection and storage were done following standard procedures [5, 16, 24].

Sowing was done during the first week of March of 2000 in cylindrical $1 \mathrm{~L}$ pots, which were built using PVC pipe sections $300 \mathrm{~mm}$ length and $70 \mathrm{~mm}$ of inner diameter. A jar lid of suitable size was fixed to the bottom of each pipe section to facilitate drainage. The pots were filled with sand and nutrients were supplied by using a slow-liberation fertilizer (Osmocote Plus, Sierra Chemical, Milpitas, USA). Plants were kept in a shade tunnel (60\% of full sunlight), leading to ca. $25 \mathrm{~mol}$ photon $\mathrm{m}^{-2}$ day $^{-1}$ of photosynthetically active radiation during clear spring days. Seedlings were arranged randomly according to their species in the tunnel. Seedling morphology was similar for plants grown inside and outside the tunnel, despite shade tunnels modify the ratio between diffuse and direct ratio. Seedlings were properly watered throughout the experiment. The mean temperature during the growing season (March-August) was $20^{\circ} \mathrm{C}$, and the relative air humidity ranged $60-90 \%$. Five individuals per species were randomly selected and tagged fixing the geographical orientation $(\mathrm{N}-\mathrm{S})$ of each plant with color marks on the container. The precise orientation of the plants was necessary for subsequent processing and measurement. Measurements were done when the last leaf flush was completed in mid August. Plants were harvested at the end of August.

\subsection{Light harvesting estimation}

The efficiency of light harvesting $\left(E_{a}\right)$ of each individual plant was calculated using the 3-D computer model Y-plant [32]. $E_{a}$ ranges between 0 and 1 , and it is defined as the mean daily photosynthetic flux density (PFD) of photons per unit leaf area absorbed by the plant divided by PFD incident on a horizontal surface right above the plant [44]. Y-plant yields an estimation of the lightharvesting efficiency and corresponding photosynthesis values for a three-dimensional model of plants by the simulation of the sun path during a given day. The crown architectural information required by Y-plant was obtained from measurements on at least five individuals per species. At each node within the crown, the internode and petiole angles and azimuths, the angle and azimuth of the leaf surface normal, and the azimuth of the midrib were recorded with a compassprotractor. Leaf, petiole, and internode lengths were measured with 
Table I. Information on the studied Quercus species: leaf habit (E: evergreen, D: deciduous); geographical distribution expressed as latitudinal (Lat) and longitudinal (Long) range centroids (mean latitude and longitude of all $50 \times 50 \mathrm{~km}$ cells occupied by the species); climatic data of regions where seeds were taken, $\mathrm{P}_{\mathrm{S}} / \mathrm{P}$ : summer and annual total precipitation; $\mathrm{T}_{\mathrm{J}} / \mathrm{T}_{\mathrm{A}}$ : mean of January and August temperatures, respectively. Distribution and climatic data were taken from several sources for European [6,18] and North American [4] species.

\begin{tabular}{lcccccc}
\hline Species & Leaf habit & Lat $\left({ }^{\circ} \mathrm{N}\right)$ & Long W/E $\left({ }^{\circ}\right)$ & $\mathrm{P}_{\mathrm{S}} / \mathrm{P}(\mathrm{mm})$ & $\mathrm{T}_{\mathrm{J}} / \mathrm{T}_{\mathrm{A}}\left({ }^{\circ} \mathrm{C}\right)$ & Leafing pattern \\
\hline Q. alba & $\mathrm{D}$ & 37.0 & $82.0 \mathrm{~W}$ & $300 / 850$ & $-5 / 20$ & Sequential \\
Q. coccifera & $\mathrm{E}$ & 40.0 & $7.5 \mathrm{E}$ & $30 / 400$ & $8 / 25$ & Sequential \\
Q. faginea & $\mathrm{D}$ & 40.1 & $3.7 \mathrm{~W}$ & $60 / 750$ & $6 / 23$ & Sequential \\
Q. ilex & $\mathrm{E}$ & 39.9 & $4.0 \mathrm{~W}$ & $40 / 600$ & $6 / 22$ & Sequential \\
Q. pyrenaica & $\mathrm{D}$ & 42.5 & $3.3 \mathrm{~W}$ & $70 / 1000$ & $5 / 20$ & Sequential \\
Q. robur & $\mathrm{D}$ & 50.4 & $12.7 \mathrm{E}$ & $200 / 1600$ & $5 / 17$ & Sequential \\
Q. rubra & $\mathrm{D}$ & 40.0 & $80.0 \mathrm{~W}$ & $300 / 900$ & $-6 / 17$ & Sequential \\
Q. suber & $\mathrm{E}$ & 40.4 & $1.2 \mathrm{E}$ & $30 / 800$ & $9 / 23$ & Simultaneous \\
\hline
\end{tabular}

a ruler and petiole and internode diameters were measured with digital callipers. A node or internode in Y-plant are not identical to an actual node or internode since true nodes were skipped if the leaves had been shed and if no branching occurred at them. An internode may therefore contain one or more actual true nodes. The nodes were numbered proceeding from the base to the top of the plant and along each branch. By recording the mother node (the node from which a subsequent node arises) for each node, the proper topology of the shoot could be reconstructed by Y-plant using the geometrical information. Leaf shape was established from $x-y$ coordinates of the leaf margins. Leaf size was then scaled in the crown reconstruction from the measured leaf length. Curved leaves were reconstructed by addition of successive leaf sections of different elevation angles as done elsewhere [47].

Light conditions of the shade tunnel where plants were growing were recorded during two months with Ha-Li light sensors (EIC SL, Madrid, Spain) cross-calibrated with a LI-190SA quantum sensor (Li-Cor, Lincoln, Nebraska, USA). Light sensors were connected to data loggers (HOBO 8, Onset, USA) and disposed in several locations within the tunnel. From the irradiance data obtained, the solar constant value required by Y-plant was set at $1150 \mu \mathrm{mol} \mathrm{m} \mathrm{m}^{-2} \mathrm{~s}^{-1}$ and rendered accurate simulations of the mean light availability of the plants. Since last leaf flush was completed for all species by August 15 th, this date was chosen to run all the simulations.

\subsection{Morphological measurements}

To obtain additional parameters related to morphology and biomass allocation, the following additional measurements were performed: (1) internode lengths of each plant to calculate the coefficient of variation of internode length (CV); (2) the diameter/height relationship $(\mathrm{D} / \mathrm{H})$ for each seedling; (3) an allocation analysis considering the dry mass of the different components of the seedlings (stems, branches, petioles, leaves) to derive leaf mass per area (LMA) and leaf area ratio of the shoot $\left(\mathrm{LAR}_{\text {shoot }}\right.$, leaf area divided by the dry mass of stems + branches + petioles + leaves); (4) leaf area of individual leaves to calculate mean leaf area (MLA). Structural dry mass is considered as the fraction (\%) of above ground biomass represented by stems, branches and petioles, i.e. the dry mass of (stems + branches + petioles) divided by the dry mass of (stems + branches + petioles + leaves). Leaf area was measured using a leaf area meter (Area Measurement System, Delta-T Devices). Dry mass of seedlings components was determined after $48 \mathrm{~h}$ at $80{ }^{\circ} \mathrm{C}$.

\subsection{Statistical analyses and ordination methods}

The normality of all quantitative morphological variables was previously checked. All analysed variables $\left(E_{a}, \mathrm{D} / \mathrm{H}, \mathrm{CV}, \mathrm{LMA}\right.$, $\mathrm{LAR}_{\text {shoot }}$, number of leaves, MLA) were normally distributed (Kolmogorov-Smirnov test, $p>0.05, Z=0.89-1.24, n=43$ ). One-way ANOVAs were performed using these variables to compare mean values among the species. Unplanned comparisons were carried out among mean species values for the selected variables using the Student-Newman-Keuls (SNK) test. Finally, in order to ordinate oak species according to the selected variables we did a principal component analysis (PCA) using individual values [41]. The PCA was carried out to explore form-functional grouping of species according to crown architecture and light harvesting. The PCA was based on the covariance matrix since the studied variables were measured in different units. Errors are expressed as standard error throughout the text.

\section{RESULTS}

Plant crown architecture and leaf morphology differed significantly among the seedlings of the different species (Fig. 1). Mean leaf area (MLA) was significantly $(p<0.01)$ related to all morphological variables studied, with most variables $(\mathrm{CV}$, $\mathrm{D} / \mathrm{H}, \mathrm{LAR}_{\text {shoot }}, E_{a}$ ) positively related ( $\left.r=0.84-0.96\right)$ to MLA (Tab. II). However, the number of leaves exhibited a negative relationship with MLA and the rest of variables, specially light harvesting efficiency ( $E_{a}$, Tab. II; Fig. 2).

The mean values of the morphological variables studied were significantly different among oak species (one-way ANOVAs, $p \leq 0.05$ ). Species from Mediterranean environments showed the highest number of leaves, lowest mean and total leaf areas, and the lowest $\mathrm{LAR}_{\text {shoot }}$ (Fig. 3). Mediterranean species also showed the lowest coefficient of variation of internode length and diameter/height ratio, whereas they showed the highest leaf mass per area (Fig. 4). We did not observe any clear grouping of the species based on the fraction of structural dry mass.

Mean light harvesting efficiency $\left(E_{a}\right)$ ranged from 0.55 to 0.77 and significantly differed among the species, leading to four distinct groups (Fig. 5). The first component of the PCA explained $94 \%$ of the overall variability and was positively associated with all variables except number of leaves, whereas 


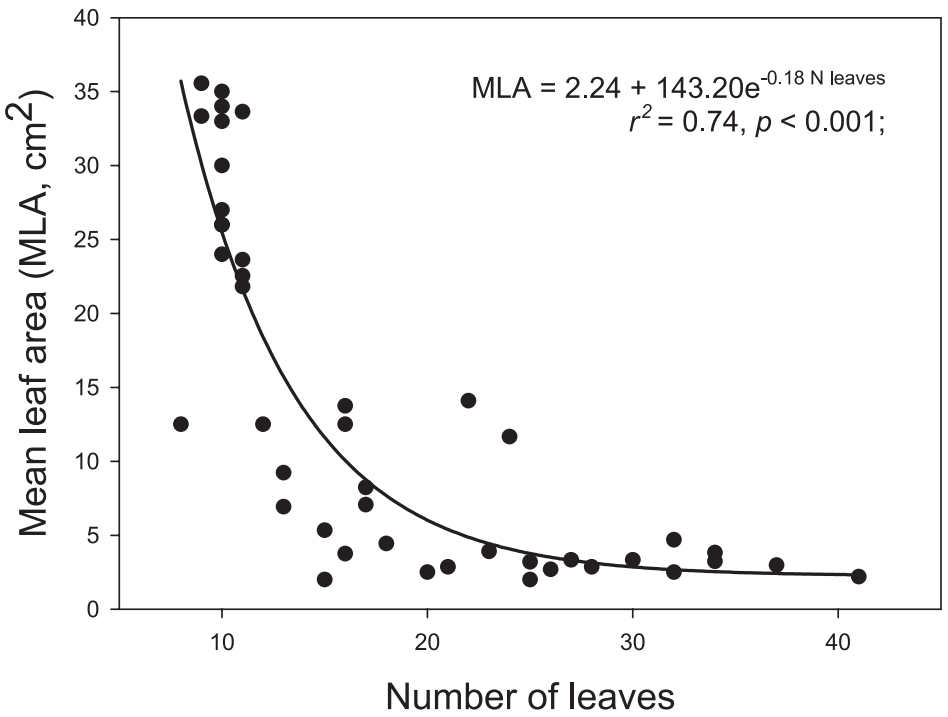

Figure 2. Negative relationship between mean leaf area and number of leaves for all Quercus seedlings studied.
Table II. Correlation values (Pearson coefficient) between the analysed morphological variables $(\mathrm{CV}$, coefficient of variation of internode length; $\mathrm{D} / \mathrm{H}$, diameter/height ratio; $\mathrm{LAR}_{\text {shoot, }}$ leaf area ratio; number of leaves; $E_{a}$, light harvesting efficiency; MLA, mean leaf area; LMA, leaf mass per area) and the scores of the first two components of the PCA (PC1, PC2). All correlation values were significant $(p \leq 0.01)$ except underlined values $(p>0.05)$.

\begin{tabular}{lccccccc}
\hline & $\mathrm{CV}$ & $\mathrm{D} / \mathrm{H}$ & $\mathrm{LAR}_{\text {shoot }}$ & $\mathrm{N}$. leaves & $E_{a}$ & MLA & LMA \\
\hline $\mathrm{D} / \mathrm{H}$ & 0.74 & & & & & & \\
LAR $_{\text {shoot }}$ & 0.91 & 0.85 & & & & & \\
N. leaves & -0.74 & -0.82 & -0.80 & & & & \\
$E_{a}$ & 0.71 & 0.72 & 0.77 & -0.86 & & & \\
MLA & 0.84 & 0.79 & 0.93 & -0.73 & 0.75 & & \\
LMA & -0.89 & -0.98 & -0.93 & 0.96 & -0.84 & -0.82 & \\
PC1 & 0.91 & 0.85 & 0.99 & -0.82 & 0.78 & 0.93 & -0.93 \\
PC2 & $\underline{0.01}$ & $\underline{-0.21}$ & $\underline{0.03}$ & 0.57 & -0.37 & $\underline{0.06}$ & $\underline{0.26}$ \\
\hline
\end{tabular}

the second component explained the remaining 6\%, and it was related to light harvesting efficiency and the number of leaves (Tab. II). The mean values of the first component scores ordered the species in these groups: (i) Q. alba, Q. rubra; (ii) $Q$. pyrenaica, $Q$. robur; (iii) $Q$. faginea, $Q$. coccifera; and (iv) Q. ilex, $Q$. suber (Fig. 6). This ranking corresponded approximately to a gradient of decreasing $E_{a}$ and increasing number of leaves. Oak species from temperate-mesic sites showed a combination of high $E_{a}$ and low number of relatively large leaves (e.g., Q. alba, Q. rubra), whereas Mediterranean oaks showed the opposite characteristics (e.g., Q. coccifera, Q. suber).

\section{DISCUSSION}

The reduction of leaf size and total foliage area, thick leaves, high leaf mass per area, and other features are associated to plant species from hot and dry environments. These traits have been considered as adaptations to reduce transpiration [31,37-39]. In agreement with this, we observed the lowest mean and total leaf areas in seedlings of Mediterranean oaks (Fig. 3). The reduction in the mean area of individual leaves resulted in a non-linear increase in the total number of leaves of the plant (Fig. 2). This combination of decreasing leaf size and increasing number of leaves occurs in species with a reduced growth rate, which leads to a new trade-off may because a high number of leaves must be arranged in a reduced stem length [49]. The simplest solution to minimize self-shading is the arrangement of the leaves in a multilayered crown [17]. Thus, the low light-harvesting efficiency of Mediterranean oak seedlings (e.g., Q. suber) could be simply the result of arranging a large number of leaves along a stem whose growth rate is low. Similarly, species mean leaf size and self-shading explained most of the variance in light capture of many perennial plants coexisting in Australia temperate forests [11]. Our findings are consistent with results from simulation studies based on virtual plants which found that the higher self-shading was due both to crowding of leaves close to each other and to proximity of leaves to the stem $[11,25,33,45,47,50]$.

Mediterranean Quercus species showed a number of morphological similarities despite having different leaf developemntal patterns. For instance, $Q$. ilex and $Q$. coccifera show a predeterminate growth model with differentiable growth cycles along the summer. However, the two of them present an architecture almost identical to that of $Q$. suber, which shows indeterminate continuous growth and flushing leafing. Therefore, the developmental pattern of leaf emergence does not seem to fully determine the associated ligh-harvesting efficiency of oak seedlings, which is influenced by additional factors.

The oak species formed four distinct groups according to their light-harvesting efficiency (Fig. 5). This classification showed two extreme groups corresponding to oaks with the highest efficiency from temperate-mesic environments (e.g., $Q$. alba, Q. rubra) and oaks with the lowest efficiency from Mediterranean environments (e.g., Q. suber). However, oaks from transitional (e.g., $Q$. faginea, $Q$. pyrenaica), temperate 

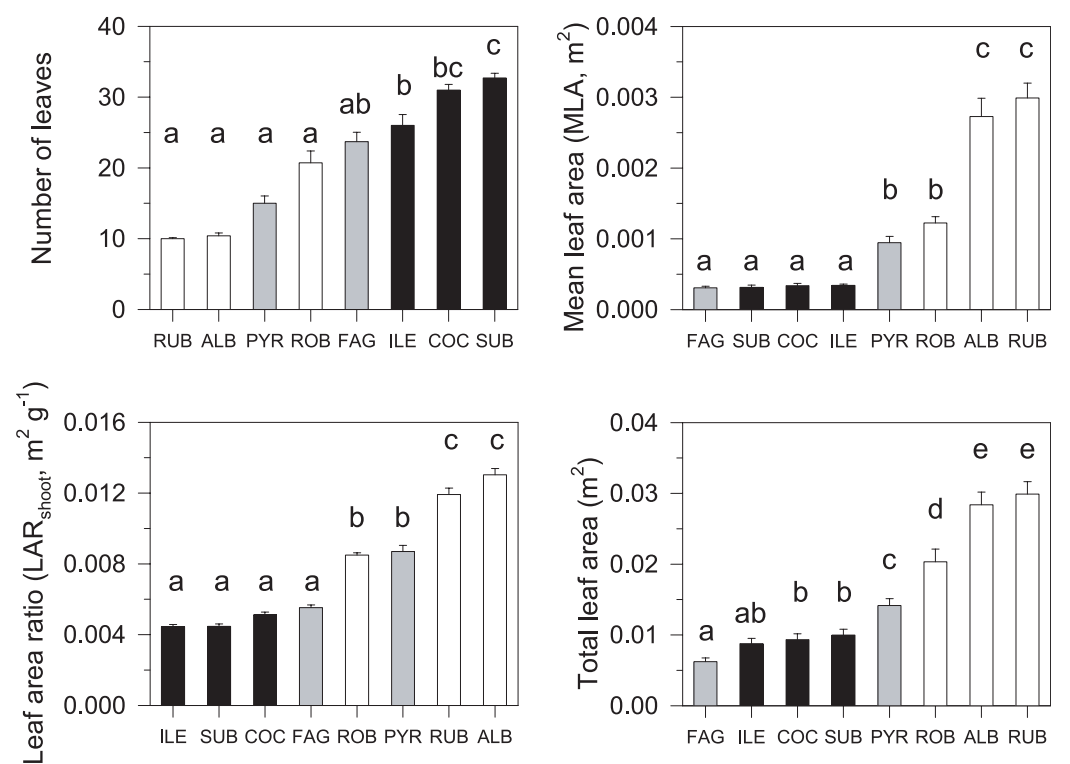

\section{Species}
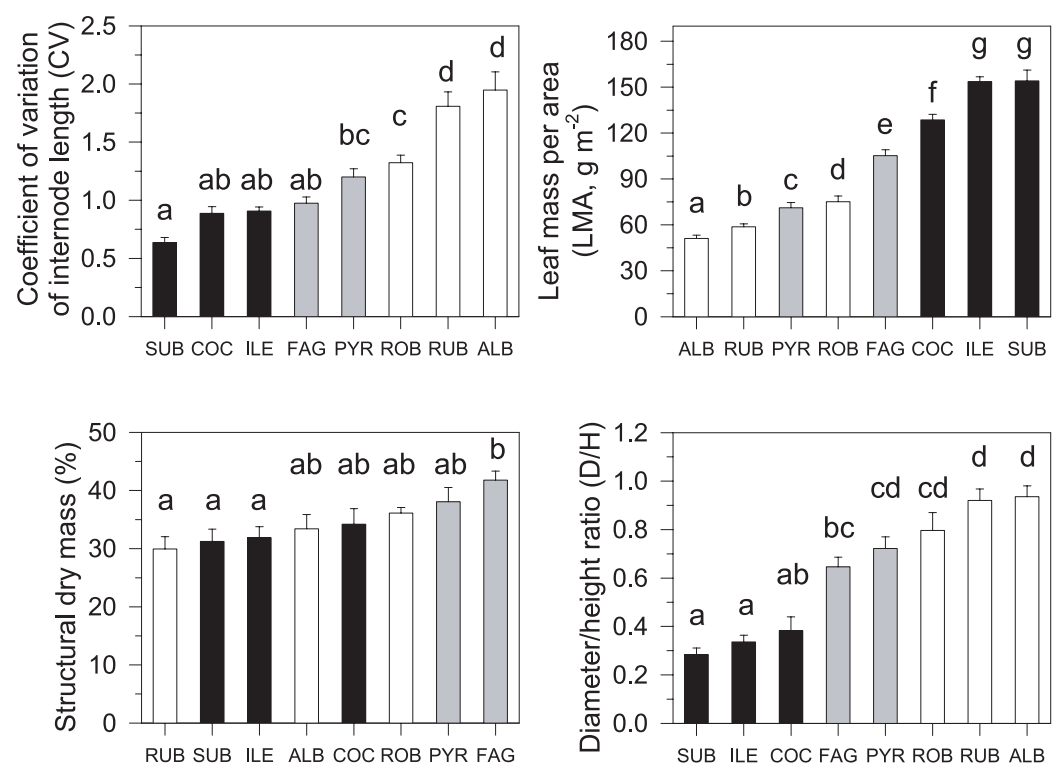

\section{Species}

Figure 3. Ranked mean values of selected morphological variables related to leaves (number of leaves; MLA, mean leaf area; $\mathrm{LAR}_{\text {shoot }}$, leaf area ratio of the shoot; total leaf area) for the studied Quercus species. The different fill colors correspond to different leaf habits and environments: evergreen Mediterranean oaks, black bars; deciduous transitional sub-Mediterranean oaks, grey bars; deciduous temperate-mesic oaks, white bars). Species abbreviations: ALB, Q. alba; COC, Q. coccifera; FAG, Q. faginea; ILE, Q. ilex; PYR, Q. pyrenaica; ROB, $Q$. robur; RUB, $Q$. rubr; SUB, $Q$. suber. Different letters indicate significant differences among species (SNK test, $p \leq 0.05$ ). Error bars are SE.
Figure 4. Ranked mean values of selected morphological variables $(\mathrm{CV}$, coefficient of variation of internode length; LMA, leaf mass per area; structural dry mass; D/H, diameter/height ratio) for the studied Quercus species. Symbols and abbreviations as in Figure 3. (e.g., Q. robur) and Mediterranean environments (e.g., $Q$. ilex, $Q$. coccifera) formed two groups with intermediate lighharvesting efficiencies. The heterogeneity of these last groups suggests that the classification of oak species based solely on their light-harvesting efficiency did not group them according to their contrasting provenance environments excepting the extreme cases.

The grouping of oaks species based on their morphological traits and their light-harvesting efficiency provided a better classification scheme according to the provenance environments of the species. The ordinations derived from principal component analysis established two contrasting morphologi- cal models, which were illustrated by $Q$. rubra and $Q$. suber (Fig. 6). These two oak species occupied extreme positions according to their mean number of leaves, leaf size, variation in internode length and light-harvesting efficiency due to their divergent developmental patterns. These distinct developmental patterns were found in oaks from contrasting provenance environments: temperate-mesic (e.g., $Q$. rubra) vs. Mediterranean environments (e.g., Q. suber), with intermediate patterns for species from transitional environments (e.g., Q. faginea).

Our findings agree with the models of leaf and stem development proposed by Kikuzawa [19]. Q. rubra displayed its foliage as pseudo-whorls located at the end of long internodes 

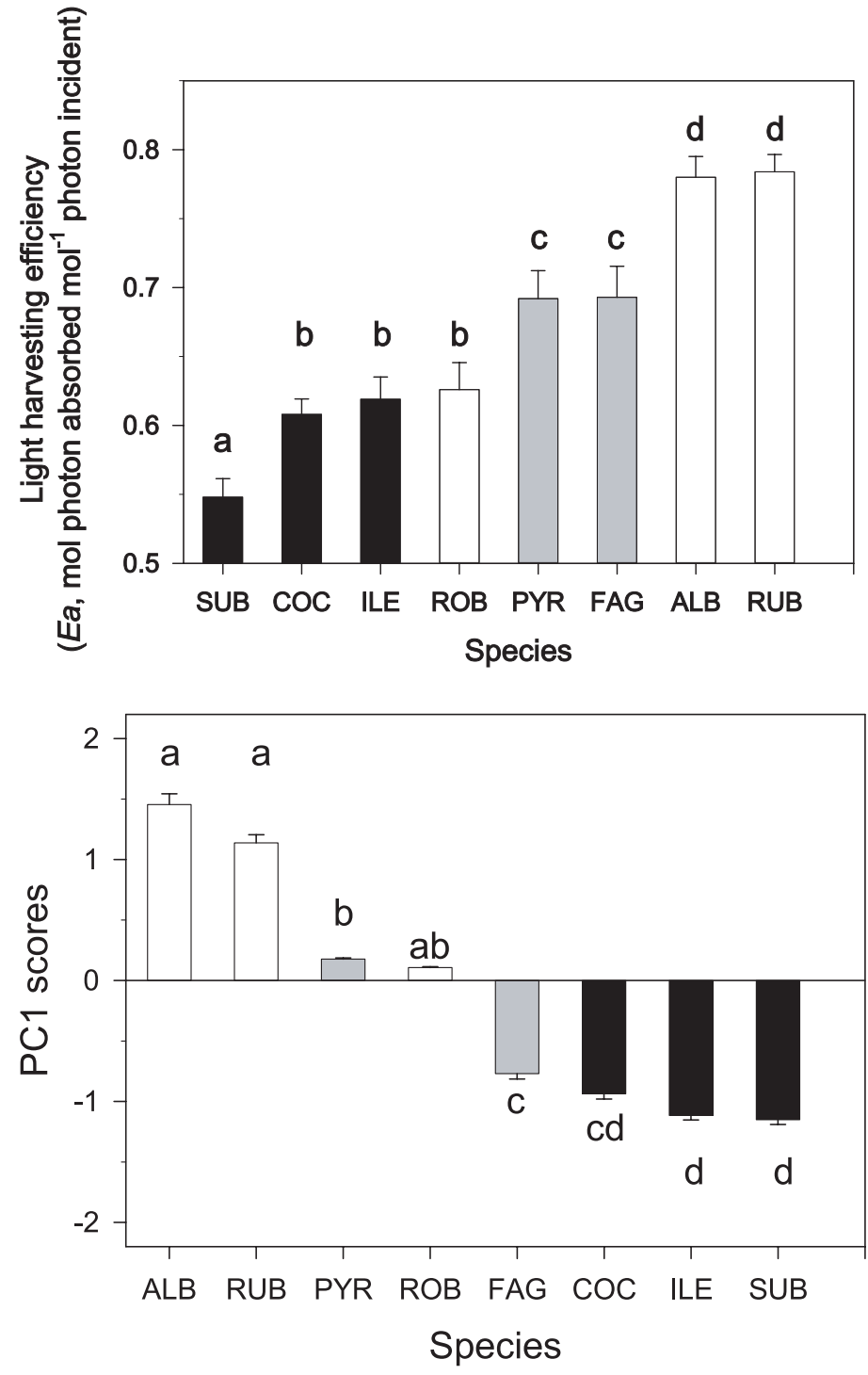

formed through cyclic growth and synchronous leaf expansion, whereas $Q$. suber showed a continuous height growth and intermediate periods between consecutive leaf expansions. The $Q$. rubra model has been associated to light-limited environments because synchronous leaf expansions in monolayers results in an effective strategy for maximizing light capture and carbon gain along the growth season [19]. Synchronous leaf expansion minimizes self-shading, which in turn allows for a near-optimal photosynthetic performance of most of the leaves of the crown under low-irradiance conditions $[43,46]$. Contrastingly, the continuous growth strategy of $Q$. suber is related to environments characterized by excessive light. In this case, leaves show a high photosynthetic potential that decreases quickly over time with new leaves constantly replacing old leaves. In this way, the negative effects of selfshading on the carbon gain of old leaves are mitigated.

The basic feature observed among the studied oak species to maximize light-harvesting efficiency was the arrangement of leaves in mono-layers. Although many structural solu-
Figure 5. Ranked mean light harvesting efficiencies $(E a)$ for the studied Quercus species. Symbols and abbreviations as in Figure 3.

Figure 6. Ranked mean scores of the first principal component from the PCA for each Quercus species. Symbols and abbreviations as in Figure 3.

tions may be adopted to achieve this including stem inclination, leaf rotation, branching, and petiole enlargement [17], the studied Quercus species formed leaf layers by generating pseudo-whorls. This was achieved through an extreme shortening of consecutive internodes. The need for having more than one leaf flush involves a great elongation of the internodes occurring between successive pseudo-whorls to reduce mutual shading among neighbour pseudo-whorls. The coefficient of variation of internode length of this pattern was significantly higher than that of successive leafing. Variations in the length of the internodes, leaf size and number of leaves has allowed Quercus species to adopt a remarkable architectural diversity without significant differences in allocation to supporting biomass (Figs. 4 and 5). The oak species studied could be arranged according to their functional and structural crown architectures, and this arrangement was consistent with their environmental conditions. Similar ordinations have been found according to traits related to water-stress resistance [9], which suggests that oak species from Mediterranean, 
transitional sub-Mediterranean and mesic environments are distinctive functional groups. However, inferences based on interspecific trait rankings from seedlings to adult plants in the field must be done with great caution [10].

The low light-harvesting efficiency due to self-shading observed in Mediterranean Quercus species might be an adaptation to high-irradiance environments [43]. Tolerance to drought involves a number of morphological adaptations, some of which conflict with the maximization of light capture for photosynthesis [36]. For instance, Mediterranean oaks such as $Q$. suber, $Q$. ilex and $Q$. coccifera are evergreen species and invest a large fraction of biomass in each individual leaf (Fig. 4). Seedlings of Mediterranean oaks can avoid high light stress due to the exposure to high irradiance by the protection of a large fraction of their foliar area, which is not displayed [46]. The low light-harvesting efficiency can be favourable considering a long-term carbon balance of the plant [42]. While all plants exhibit a relatively high capacity for physiological protection against excessive irradiance [26], only those from xeric sites exhibit architectural and morphological features that prevent them from surpassing the physiological limits of tolerance [43]. We acknowledge the fact that our experiments were carried out in moderately shaded environments, which may influence the suggested hypothesis on this trade-off between maximizing light harvesting and avoiding high-light stress. However, we required a similar light environment for the studied oak seedlings to compare their morphological response and the moderate shade provided the most appropiate light environment for these species.

Light harvesting efficiency of the studied oak seedlings ranged from 0.55 to 0.77 , i.e. a $20 \%$ difference, despite being related species grown under similar light environments. This conclusion is in contrast with the idea that plastic phenotypic adjustments of crown architecture are the primary determinants of light capture in plants $[28,47]$. Leaf angle, leaf size and internode length are very plastic features, but phylogenetic constrains also determine the light harvesting efficiency of a given plant species. Future studies should assess if the intrinsic cost of the crown architecture of Mediterranean oak seedlings in terms of light capture may be an evolutionary stable strategy, i.e. if the potential advantages such avoiding high light stress compensate for this cost.

Acknowledgements: This work was supported by 1FD97-0911C03-01 project (Subpr. 1) and INIA grant to JEM. JJC acknowledges the support of a INIA-Gob. Aragón postdoctoral contract. Collaborative work was made possible by the thematic network GLOBIMED funded by the Spanish Ministry of Education and Science (www.globimed.net).

\section{REFERENCES}

[1] Amaral Franco J., Quercus L., in: Castroviejo S., Laínz M., López G., Montserrat P., Muñoz F., Paiva J., Villar L. (Eds.), Flora Ibérica II: Plantas Vasculares de la Península Ibérica e Islas Baleares, RJBM-CSIC, Madrid, 1990, pp. 16-36.

[2] Aphalo P.J., Ballaré C.L., Scopel A.L., Plant-plant signalling, the shade-avoidance response and competition, J. Exp. Bot. 50 (1999) $1629-1634$
[3] Balaguer L., Martínez-Ferri E., Valladares F., Pérez-Corona M.E., Baquedano F.J., Castillo F.J., Manrique E., Population divergence in the plasticity of the response of Quercus coccifera to the light environment, Funct. Ecol. 15 (2001) 124-135.

[4] Burns R.M., Honkala B.H., Silvics of North America, 2: Hardwoods. USDA, Washington, 1990.

[5] Catalán-Bachiller G., Semillas de árboles y arbustos forestales, MAP-ICONA, Madrid, 1991.

[6] Ceballos L., Ruiz de la Torre J., Árboles y arbustos de la España peninsular, ETSIM, Madrid, 1979.

[7] Collet C., Guehl J.M., Frochot H., Ferhi A., Effect of two forest grasses differing in their growth dynamics on water relations and the growth of Quercus petraea seedlings, Can. J. Bot. 74 (1996) 1562-1571.

[8] Collet C., Ningre F., Frochot H., Modifying the microclimate around young oaks through vegetation manipulation: Effect on seedling growth and branching, For. Ecol. Manage. 110 (1998) 249262 .

[9] Corcuera L., Camarero J.J., Gil-Pelegrín E., Functional groups in Quercus species derived from the analysis of pressure-volume curves, Trees 16 (2002) 465-472.

[10] Eliáš P., Effects on the canopy position on shoots and leaves in various trees of an oak-hornbean forest, Biológia 45 (1990) 31-42.

[11] Falster D.S., Westoby M., Leaf size and angle vary widely across species: what consequences for light interception? New Phytol. 158 (2003) 509-525.

[12] George L.O., Bazzaz F.A., The fern understory as an ecological filter: emergence and establishment of canopy-tree seedlings, Ecology 80 (1999) 833-845

[13] Gottschalk K.W., Shade, leaf growth and crown development of Quercus rubra, Quercus velutina, Prunus serotina and Acer rubrum seedlings, Tree Physiol. 14 (1994) 735-749.

[14] Govaerts R., Frodin D.G., World checklist and bibliography of Fagales (Betulaceae, Corylaceae, Fagaceae and Ticodendraceae), The Royal Botanic Gardens, Kew, 1998.

[15] Grassi G., Giannini R. Influence of light and competition on crown and shoot morphological parameters of Norway spruce and silver fir saplings, Ann. For. Sci. 62 (2005) 269-274.

[16] Gribko L.S., Jones W.E., Test of the float method of assessing northern red oak acorn condition, Tree Planters' Notes 46 (1995) 143147.

[17] Horn H., Adaptative Geometry of Trees, Princeton Univ. Press, New Jersey, 1971.

[18] Jalas J., Suominen J., Lampinen R., Atlas Florae Europaeae (http://www.helsinki.fi/kmus/afe.html), 1999.

[19] Kikuzawa K., Leaf phenology as an optimal strategy for carbon gain in plants, Can. J. Bot. 73 (1995) 158-163.

[20] Kikuzawa K., Koyama H., Umeki K., Lechowitz M.J., Some evidence for an adaptative linkage between leaf phenology and shoot architecture in sapling trees, Funct. Ecol. 10 (1996) 252-257.

[21] Krüssmann G., Manual of Cultivated Broad-leaves Trees and Shrubs, Vol. III, Timber Press, Portland, 1986.

[22] Kursar T.A., Coley P.D., Contrasting modes of light acclimation in two species of the rainforest understory, Oecologia 121 (1999) 489498.

[23] Matthes-Sears U., Larson D.W., Limitations to seedling growth and survival by the quantity and quality of rooting space: implications for the establishment of Thuja occidentalis on cliff faces, Int. J. Plant Sci. 160 (1999) 122-128.

[24] Merouani H., Branco C., Almeida M.H., Pereira J.S., Comportement physiologique des glands de chêne liège (Quercus suber L.) durant leur conservation et varibilité inter-individus producteurs, Ann. For. Sci. 58 (2001) 143-153. 
[25] Muraoka H., Koizumi H., Pearcy R.W., Leaf display and photosynthesis of tree seedlings in a cool-temperate deciduous broadleaf forest understory, Oecologia 135 (2003) 500-509.

[26] Niinemets U., Kollist H., García-Plazaola J.I., Hernández A., Becerril J.M., Do the capacity and kinetics for modification of xanthophyll cycle pool size depend on growth irradiance in temperate trees? Plant Cell Environ. 26 (2003) 1787-1801.

[27] Niklas K.J., The role of phyllotactic pattern as a "development constraint" on the interception of light by leaf surfaces, Evolution 42 (1988) $1-16$.

[28] Niklas K.J., Light harvesting "fitness landscapes" for vertical shoots with different phyllotactic patterns, in: Jean R.V., Barabé D. (Eds.), Symmetry in Plants, World Scientific Publishing Co., Singapore, 1998, pp. 759-773.

[29] Nixon K.C., Infrageneric classification of Quercus (Fagaceae) and typification of sectional names, Ann. Sci. For. 50 (1993) 25-34.

[30] Nygren P., Kiema P., Rebottaro S., Canopy development, $\mathrm{CO}_{2}$ exchange and carbon balance of a modelled agroforestry tree, Tree Physiol. 16 (1996) 733-745.

[31] Passioura J.B., Physiology of grain yield in wheat growing on stored water, Austr. J. Plant Physiol. 3 (1976) 559-565.

[32] Pearcy R.W., Yang W., A three-dimensional crown architecture model for assessment of light capture and carbon gain by understory plants, Oecologia 108 (1996) 1-12.

[33] Pearcy R.W., Valladares F., Wright S.J., Lasso de Paulis E., A functional analysis of the crown AFSN5-2006 architecture of tropical forest Psychotria species: do species vary in light capture efficiency and consequently in carbon gain and growth? Oecologia 139 (2004) 163-177.

[34] Pearcy R.W., Muraoka H., Valladares F., Crown architecture in sun and shade environments: assessing function and trade-offs with a three-dimensional simulation model, New Phytol. 166 (2005) 791800

[35] Piboule A., Collet C., Frochot H., Dhôte J.-F., Reconstructing crown shape from stem diameter and tree position to supply light models I. Algorithms and comparison of light simulations, Ann. For. Sci. 62 (2005) 645-657.

[36] Poole D.K., Miller P.C., The distribution of plant water stress and vegetation characteristics in southern California chaparral, Am. Midl. Nat. 105 (1981) 32-43.

[37] Rambal S., The differential role of mechanisms for drought resistance in a Mediterranean evergreen shrub: a simulation approach, Plant Cell Environ. 16 (1993) 35-44.
[38] Sisó S., Camarero J.J., Gil-Pelegrín E., Relationship between hydraulic resistance and leaf morphology in broadleaf Quercus species: a new interpretation of leaf lobation, Trees 15 (2001) 341345.

[39] Smith T.M., Huston M.L., A theory of the spatial and temporal dynamics of plant communities, Vegetatio 83 (1989) 49-69.

[40] Smolander H., Stemberg P., Linder S., Dependence of light interception efficiency of Scots pine shoots on structural parameters, Tree Physiol. 14 (1994) 971-980.

[41] Sokal R.R., Rohlf F.J., Biometry: the Principles and Practice of Statistics in Biological Research, Freeman, New York, 1995.

[42] Suárez N., Leaf longevity, construction, and maintenace costs of three mangrove species under field conditions, Photosynthetica 41 (2003) 373-381.

[43] Valladares F., Architecture, ecology and evolution of plant crowns, in: Pugnaire F.I., Valladares F. (Eds.), Handbook of Functional Plant Ecology, Marcel Dekker, New York, 1999, pp. 121-194.

[44] Valladares F., Brites D., Leaf phyllotaxis: does it really affect light capture? Plant Ecol. 174 (2004) 11-17.

[45] Valladares F., Pearcy R.W., Interactions between water stress, sunshade acclimation, heat tolerance and photoinhibition in the sclerophyll Heteromeles arbutifolia, Plant Cell Environ. 20 (1997) 25-36.

[46] Valladares F., Pearcy R.W., The functional ecology of shoot architecture in sun and shade plants of Heteromeles arbutifolia M. Roem., a Californian chaparral shrub, Oecologia 114 (1998) 1-10.

[47] Valladares F., Skillman J., Pearcy R.W., Convergence in light capture efficiencies among tropical forest understory plants with contrasting crown architectures: a case of morphological compensation, Am. J. Bot. 89 (2002) 1275-1284.

[48] Valladares F., Dobarro I., Sánchez-Gómez D., Pearcy R.W., Photoinhibition and drought in Mediterranean woody saplings: scaling effects and interactions in sun and shade phenotypes, J. Exp. Bot. (2005) 56: 483-494.

[49] Waller D.M., The dynamics of growth and form. In: Crawley M.J. (Ed.), Plant ecology, Blackwell, Oxford, 1991, pp. 291-320.

[50] Yamada T., Okuda T., Abdullah M., Awang M., Furukawa A., The leaf development process and its significance for reducing selfshading of a tropical pioneer tree species, Oecologia 125 (2000) 476-482. 